\title{
Impact of value-adding services on quality, loyalty and brand equity in the brewing industry
}

\author{
Jari Juga * \\ Jouni Juntunen $* *$ \\ Mikko Paananen ***
}

* Corresponding author: University of Oulu/ Oulu Business School, Department of Marketing, P.O. Box 4600, FI-90014 University of Oulu, Finland. E-mail:jari.juga@oulu.fi, tel: +358 50350 2953, s[sp:fax +358 8 5532906

** University of Oulu/ Oulu Business School, Department of Marketing, P.O. Box 4600, FI-90014 University of Oulu, Finland. E-mail:jouni.juntunen@ oulu.fi, tel: +358 50 3503464, fax +358 85532906. *** Bank OP Poppia, Riistakatu 7, 74100 Iisalmi, Finland. E-mail: kiesima@yahoo.com, Tel: +358 400817 036; fax: +358 1781260

\section{ABSTRACT}

\section{Purpose}

The purpose of this research is to investigate the impact of logistics value-adding services and perceived service quality on brand equity among B2B customers of a brewery company.

\section{Design/methodology/approach}

A theoretical model is developed and tested using survey data from 173 hotel, restaurant and catering industry customers of a brewery company in Finland.

\section{Findings}

Value-adding services play an important role in building the brewery company's brand equity through perceived service quality. Besides a direct impact on overall service quality, an indirect impact is detected through the operational dimension of service quality in logistics.

\section{Research limitations/implications (if applicable)}

A broader data set would be needed to generalize the findings also beyond the brewery business and the hotel, restaurant and catering industry customers in Finland.

\section{Practical implications (if applicable)}

To increase brand equity, value adding services like logistics can play an important role for B2B customers. This study is important for practitioners as well as academics since there has been little quantitative research available regarding value adding services in the context of service quality and brand equity research.

\section{Social implications (if applicable)}

\section{Original/value}

This paper combines logistics as value adding service to customers' willingness to pay extra profits in order to cooperate with service producer.

Keywords: value adding service, service quality, brand equity, structural equation modelling, brewing industry. 


\section{Introduction}

Competition in the brewing industry is intense. Big multinational companies dominate the business especially in high volume markets while smaller breweries focus on local markets and narrow customer segments. Competition is heavily based on price and strong brands, but increasingly also on auxiliary services offered to business customers such as retailers, hotels and restaurants. In many cases, at least some of these services are outsourced to external service providers such as logistics companies who take care of deliveries to customers, reverse logistics operations and shelving services in the customers' premises.

The vital role of service quality as a driver of customer satisfaction and loyalty is well established in B2C (e.g. Cronin and Taylor, 1992; Caruana 2002) and B2B (e.g. Homburg et al., 2003; Chumpitaz and Paparoidamis 2007) service contexts, including logistics outsourcing relationships (Juga et al., 2010; Cahill et al. 2010; Juga et al. 2012). The quality of value-adding services, such as after-sales services, affects the customer's satisfaction and loyalty, too (Rigopoulou et al., 2008). However, there have not been studies to specifically investigate the impact of value-adding services offered by external service providers in triadic business relationship. In the case of brewery logistics, for instance, logistics companies act as brand advocates of breweries and can thus have a significant impact on the brewery customer's loyalty.

The purpose of this study is to examine the impact of value-adding services and perceived service quality on loyalty and brand equity among B2B customers of a brewery company in Finland. Based on earlier literature, critical service dimensions are identified and their impact with value adding services on loyalty and brand equity is examined empirically with structural equation modelling (SEM) using the LISREL software package. The survey data were collected during 2013 among hotel, restaurant and catering (HoReCa) customers of one of the largest brewery companies in Finland. The company has strong brands among end customers, its lager beers have been ranked as the most valuable beer brands in Finland. However, among business customers the brands must be supported with excellent service capabilities by the company itself as well as other members in its distribution channels.

This paper is organized as follows. After the introduction, the theoretical underpinnings of the study are presented. A tentative model is created and then tested in the empirical analysis section of the study. The paper is concluded with a discussion of the theoretical contribution and managerial implications and future research suggestions.

\section{Theoretical underpinnings}

The connection between service performance and customer loyalty has been a widely studied topic in marketing and service management research. Despite the fact that service definitions vary (see e.g. Ghobadian et al., 1994; Seth et al., 2005; Ladhari, 2009) and various mediating or moderating impacts have been identified (e.g. Homburg and Giering, 2001; Bodet, 2008), a broad agreement exists that service performance increases the customer's loyalty both in B2C (e.g. Cronin and Taylor, 1992; Caruana, 2002) and in B2B (e.g. Homburg et al., 2003; Chumpitaz and Paparoidamis, 2007) service contexts. This "loyalty effect" (Reicheld et al., 
2000) or "service-profit chain" (Heskett et al., 1994) means that companies with excellent service quality keep their customers loyal and thereby improve profitability.

Some service loyalty models include customer value as a supplementary factor along with service quality (e.g. McDougall and Levesque, 2000) or - as in ACSI customer satisfaction index - a mediating factor between service quality and loyalty (e.g. Grigoroudis and Siskos, 2004). In these models, value is typically conceived as benefits that the customer gets in relation to sacrifices (price/quality relation). However, value can also be approached through the auxiliary services (value-adding services) that are offered to the customer in addition to the core service. For instance, Rigopoulou et al. (2008) found that after-sales services of a large retail chain in Greece had a positive impact on customer satisfaction and loyalty.

A number of service definitions and models have also been developed in logistics (e.g. Mentzer et al., 1999; Rafele, 2004; Rafiq and Jaafar, 2007) and the link between logistics service quality and customer loyalty has been detected in various contexts (e.g. Stank et al., 2003; Davis and Mentzer, 2006; Saura et al., 2008; Wallenburg et al., 2010). In a study of manufacturing companies in Finland, Juga et al. (2010) found that three factors - operational, personal, and technical factors - largely determined customer satisfaction and loyalty in logistics outsourcing relationships.

In a further development of the service loyalty model in logistics, Grant et al. (2014) discovered that brand equity follows customer satisfaction and loyalty in logistics outsourcing relationships. This is consistent with Davis et al. (2008) results confirming the existence of brand equity in the commodity-like logistics industry. Although the definitions vary (see e.g. Wood, 2000; Bendixen et al., 2004; Martensen and Grønholdt, 2010), brand equity in B2B markets is commonly associated with such features as brand awareness and brand image (Keller, 1998) and the willingness to pay more for the preferred brand (Hutton, 1997).

There are many variations of the loyalty effect model - the antecedent factors to customer loyalty vary as do the chains of effects: some include satisfaction or trust as a mediator between service quality and loyalty (e.g. Olsen, 2002; Caruana, 2002), some include value as a substitute for service quality (Lam et al., 2004), and relationship quality is used instead of service quality especially in B2B service contexts (e.g. Rauyruen and Miller, 2007). However, it seems that the conclusion by Ghobadian et al. (1994) is valid in any context: customers are the lifeblood of any business, and service quality can win and keep customers.

\section{Hypotheses and measures}

The model adopted in this study (see Figure 1) is based on the service loyalty model in logistics outsourcing relationships by Juga et al. (2010). It is hypothesized that experienced service performance in logistics is composed of three dimensions: operational (H1a), personal (H1b) and technical dimensions (H1c). In other words, these three dimensions form the overall service quality perception of the brewery's HoReCa customers.

The value-adding services refer to the logistics services offered to the customers by external service providers as well as the equipment (e.g. beer taps, refrigerators, etc.) and maintenance services offered by the brewery to the HoReCa customers. As it can be assumed that service providers act as brand advocates or brand carriers for the brewery, it is hypothesized that value-adding services affect the experienced service quality through the three service dimensions ( $\mathrm{H} 2 \mathrm{a}, \mathrm{H} 2 \mathrm{~b}, \mathrm{H} 2 \mathrm{c})$, creating a kind of "halo effect" that is related to the brand 
equity concept (e.g. Leuthesser et al., 1995). Following Rigopoulou et al. (2008), it is further hypothesized that value-adding services also affect the customer's overall service perception directly (H3).

Based on the assumption of direct loyalty effect in B2B service relationships (e.g. Rauyruen and Miller, 2007), it is hypothesized that service performance affects loyalty (H4) without a mediating effect of overall satisfaction. In previous research a direct impact of service performance has also been detected on brand equity (van Riel et al., 2005). Therefore it is hypothesized that service performance affects the brewery's brand equity (H5), too.

Finally, based on earlier findings (e.g. Rauyruen et al., 2009; Grant et al., 2014), it is hypothesized that customer loyalty affects brand equity (H6). Although there are also contrasting views about the direction of effects between these concepts (e.g. Aaker, 1996; Taylor et al., 2004), the impact of loyalty on brand equity is proposed in this study because of the evidence that has been presented in logistics outsourcing context (Grant et al., 2014).

\section{INSERT FIGURE 1 HERE}

\section{Research method and data}

The empirical research was conducted in 2013 as a survey study to the HoReCa customers of one of the largest brewery companies in Finland. The company has a strong brand in the consumer markets - in fact, its lager beers have been nominated as the most valuable beer brand in Finland. However, to strengthen its position in the business markets, the company offers various value-adding services to its HoReCa customers, as do other major brewery companies. These include logistics-related services that have been outsourced to external service providers and restaurant equipment such as beer taps, soft-drink dispenser and refrigerators.

The survey was e-mailed to 645 customers, which is approximately half of the company's registered domestic HoReCa customers. Two e-mails were sent and a response time of one week was set each time. A total of 173 responses $(26.8 \%)$ were obtained, which may be considered satisfactory (e.g., Larson, 2005). The first round produced 114 responses $(17.7 \%$ of the target group) and the second round (reminder) added another 59 responses $(9.1 \%)$. It may be noted that 94 (14.6\% of target group) e-mail addresses proved to be invalid (returned as "email address unknown"), which increases the effective response rate to $31 \%$.

Some of the key descriptive variables of the respondents are listed in Table 1. According to the brewery management's representative, the customers' size and business history in the sample largely comply with the company's HoReCa customer base. The two response waves were also compared using the variance analysis (ANOVA) and there were no statistically significant differences between the groups. Hence, it seems justifiable to conclude that non-response bias does not pose a serious threat to the validity of the study (Armstrong and Overton, 1977).

INSERT TABLE 1 HERE 
Structural equation modelling (SEM) with Lisrel software was used to analyze the survey data. The structural model in this study is a second-order model where theoretical concepts (or factors) are measured by statements in the survey questionnaire. Earlier studies were used to develop the measures for the theoretical concepts of the proposed model. The questions were measured on a 7-point scale, including Likert-scale attitudinal statements (fully disagree ... fully agree) and quality grades (poor ... excellent). The concepts and their operational measures used in the questionnaire are presented in Table 2.

\section{INSERT TABLE 2 HERE}

\section{Model estimation}

The proposed model was tested with confirmatory SEM analysis. It was found that there were statistically insignificant relationships and therefore it was decided to move to model generating SEM (Jöreskog, 1993) instead. In model generating SEM, the idea is to find a statistically significant model that is also theoretically valid. In this case, the model generating approach was considered appropriate as new concepts were introduced to the loyalty effect framework, and all relationships in the model have not yet been empirically validated.

Based on the results of SEM analysis, two relationships proved statistically insignificant $(\mathrm{H} 2 \mathrm{c}$ and H6) in the proposed model. Consequently, a model respecification was made by deleting the two paths from the model ( $\mathrm{H} 2 \mathrm{c}$ and $\mathrm{H} 6)$. All relationships in the amended model were statistically significant (Figure 2) and the fit indices of the model (see e.g. Browne and Cudeck, 1993; Hu and Bentler, 1999) were acceptable as can be seen in Table 3). Also the test values of the latent variables indicate acceptable statistical significance for each factor.

INSERT FIGURE 2 HERE

\section{INSERT TABLE 3 HERE}

\section{Empirical findings}

As proposed in $\mathrm{H} 1 \mathrm{a}-\mathrm{H} 1 \mathrm{c}$, three dimensions (operational, personal and technical) can be seen as constituents of the HoReCa customers' perceived service quality. The personal service dimension is the strongest dimension, followed by technical and operational service dimensions. In other words, personal service quality is the best differentiator of the brewery toward its HoReCa customers. Technical service and operational service dimensions are weaker differentiators; perhaps the systems and processes of the big breweries are fairly similar and thus appear more as qualifiers than differentiators toward the customers.

Value-adding services show a dual impact on service quality perception of the brewery's $\mathrm{HoReCa}$ customers. As proposed in $\mathrm{H} 2 \mathrm{a}$ and $\mathrm{H} 2 \mathrm{~b}$, the value-adding services affect the operational and personal service dimensions of the customer's overall quality experience. The strongest impact is on operational quality dimension $(\mathrm{H} 2 \mathrm{a})$ which is naturally explained by the logistics-related nature of this dimension. However, the value-adding services also show a 
direct impact on the customer's service perception (H3). This is an indication of the central role that the service providers play as the brewery's representative and brand advocate in daily interaction with the customer.

There is a strong support in this study for the hypothesized relationship between perceived service quality and customer loyalty (H4). In addition, the service quality perception has a parallel impact on brand equity (H5). However, no impact was detected between the loyalty intentions and brand equity (H6). As noted above, there are differing views about the nature of impacts between these concepts in previous research, which may explain the missing relationship and thereby justify the model modification.

The other modification was the rejection of the hypothesized impact of value-adding services on the technical service dimension of the customer's overall quality perception $(\mathrm{H} 2 \mathrm{c})$. Also this modification is not so surprising because the technical quality dimension (TSERV) in this study focused on information systems and information exchange, and the HoReCa customers share information electronically (also in logistics-related issues) with the breweries and not with service providers. By contrast, the operational and personal interaction takes place also with service providers and the observed impacts $\mathrm{H} 2 \mathrm{a}$ and $\mathrm{H} 2 \mathrm{~b}$ are therefore justifiable.

\section{Conclusions}

Based on the empirical findings, eight of the hypothesized relationships in the theoretical model were accepted and two rejected (see Table 4). Model respecification (removing insignificant relationships) resulted in an amended model that is statistically acceptable and may also be considered theoretically justifiable as the remaining relationships are consistent with the original framework of the study.

\section{INSERT TABLE 4 HERE}

The results show that value-adding services can play a vital role in creating customer loyalty and brand equity. In other words, the customers are not only willing to continue the relationship with the brewery but may also pay more as a result of the value-adding services provided to them. Especially in highly competitive industries, such as the brewery industry, auxiliary services that are often outsourced to external service providers offer a way to differentiate the company, enhance customer loyalty and increase profitability. Thus, the producer companies should not see their service providers as cost items only but as value co-creators and brand advocates that advance their competitiveness.

From a theoretical perspective, this study contributes to the rich tradition of service quality research by including the concept of value-adding service into the loyalty effect model. The observed dual impact of value-adding services on customer's quality perception raises continuing research opportunities about the existence of halo effect (or spill-over effect) and brand advocacy of external service providers. The halo effect explains the bias shown by customers towards certain products because of favourable experiences with other products of the same maker - it has thus much in common with the brand equity concept (e.g. Leuthesser et al., 1995). However, its implications have not been widely studied in service industry settings especially when multiple actors are involved in creating the overall service offering. 
Research is also needed to further investigate the concept of brand equity and its consequences in B2B service contexts. Brand equity is commonly seen as an antecedent to brand loyalty (e.g. Taylor et al., 2004; van Riel et al., 2005), but studies in industrial branding have shown also contrasting results (e.g. Bendixen et al., 2004; Leek and Christodoulides, 2011). According to Rauyruen et al. (2009) and Grant et al. (2014), loyalty is the antecedent to brand equity while Juntunen et al. (2011) observed, much in line with the results of the present study, that loyalty and brand equity are parallel outcomes and not consequential. Following Krishnan and Hartline (2001), it may be said that more empirical research is needed to examine the presumptions regarding brand equity in services that mostly stem from conceptual or anecdotal evidence.

In a triadic or network setting the relationships get more complicated and the logic of branding shifts towards relational assets and interactions between actors (see e.g. Jones, 2005; Ballantyne and Aitken, 2007). This kind of shift towards interactive social processes may also have implications on research methodology: a number of scholars oppose the linear models of branding and address the need for more interpretive approaches to extend the understanding of corporate branding from a multi-stakeholder perspective (see e.g. Cornelissen et al., 2012; Mäläskä, 2015).

This study is limited to the B2B customers of one company and one country, which means that more studies are needed in different industry contexts to achieve more generalizable findings. Besides logistics, also other value-adding services and their impacts should be investigated. It is possible that different customer segments assess the importance of service elements differently (Mentzer et al., 2001), which calls for other analytical tools such as latent class analysis (see e.g. Juntunen et al. 2015) for model estimation. Also the service providers' commitment and motivational drivers would offer interesting research opportunities to shed light on their role as brand advocates for their partner companies. 


\section{References}

Aaker, D.A. (1996), Building Strong Brands. The Bath Press: Bath.

Armstrong, J.S. and Overton, T.S. (1977), Estimating nonresponse bias in mail surveys, Journal of Marketing Research, Vol. 14 No. 3, pp. 396-402.

Ballantyne D and Aitken R (2007) Branding in B2B markets: insights from the servicedominant logic of marketing. Journal of Business \& Industrial Marketing Vol. 22 No 6, pp. 363-371.

Bendixen, M., Kalala, A.B. and Abratt, R. (2004), Brand equity in the business-tobusiness market. Industrial Marketing Management, Vol. 33 No 5, pp. 371-380.

Bodet, G. (2008), Customer satisfaction and loyalty in service: Two concepts, four constructs, several relationships. Journal of Retailing and Consumer Services, Vol. 15 No 3, pp. 156-162.

Browne, M. W. and Cudeck, R. (1999) Alternative ways of assessing model of fit. In: Bollen, K. and Long, J.S. (eds.) Testing Structural Equation Models. Sage. Newbury Park CA.

Cahill, D., T. J. Goldsby, M. A. Knemayer, and C. M. Wallenburg (2010), Customer Loyalty in Logistics Outsourcing Relationships: An Examination of the Moderating Effects of Conflict Frequency. Journal of Business Logistics Vol. 31 No, pp. 253-277.

Caruana, A. (2002) Service loyalty: The effects of service quality and the mediating role of customer satisfaction. European Journal of Marketing, Vol. 36, No 7/8, pp. 811-828.

Chumpitaz C.R. and Paparoidamis N.G. (2007), Service quality, relationship satisfaction, trust, commitment and business-to-business loyalty. European Journal of Marketing, Vol. 41, No 7/8, pp. 836-867.

Cornelissen, J., Christensen, L.T. and Kinuthia, K. (2012), Corporate brands and identity: developing stronger theory and a call for shifting the debate. European Journal of Marketing, Vol. 47 No 7, pp. 1093-1102.

Cronin, J.J. and Taylor, S.A. (1992), Measuring Service Quality: A Reexamination and Extension. Journal of Marketing, Vol. 56 No 3, pp. 55-68.

Davis, B.R. and Mentzer, J.T. (2006), Logistics Service Driven Loyalty: An Exploratory Study. Journal of Business Logistics, Vol. 27 No 2, pp. 53-73.

Davis, D. F., Golicic, S.L. and Marquardt, A.J. (2008) Branding a B2B service: Does a brand differentiate a logistics service provider? Industrial Marketing Management, Vol 37 No 2, pp. $218-227$.

Ghobadian, A., Speller, S. and Jones, M. (1994), Service quality: Concepts and models. International Journal of Quality and Reliability Management, Vol. 11, No 9, pp. 43-66.

Grant, D.B., Juntunen, J., Juga, J. and Juntunen, M. (2014) Investigating brand equity of third-party service providers. Journal of Services Marketing, Vol. 28 No 3, pp. 214-222.

Grigoroudis, E. and Siskos, Y. (2004), A survey of customer satisfaction barometers: Some results from the transportation-communiations sector. European Journal of Operational Research, Vol. 152 No 2, pp. 334-353.

Heskett, J.L., Jones, T.O., Loveman, G.W., Sasser W.E. Jr and Schlesinger, L.A. (1994), Putting the service-profit chain to work. Harvard Business Review, Vol. 72 No 2, pp. 105111. 
Homburg, C. and Giering, A. (2001), Personal characteristics as moderators of the relationship between customer satisfaction and loyalty: An empirical analysis. Psychology and Marketing, Vol. 18 No 1, pp. 43-66.

Homburg, C., Giering, A. and Menon, A. (2003), Relationship characteristics as moderators of the satisfaction-loyalty link: Findings in a business-to-business context. Journal of Business-to-Business Marketing, Vol. 10 No 3, pp. 35-62.

Hu, L.-T. and Bentler, P.M. (1999) Cutoff criteria for fit indexes in covariance structure analysis: Conventional criteria versus new alternatives. Structural Equation Modeling, Vol 6 No 1, pp. 1-55.

Hutton, J.G. (1997), A study of brand equity in an organizational-buying context. Journal of Product and Brand Management, Vol. 6 No 6, pp. 428-439.

Jones R (2005) Finding sources of brand value: Developing a stakeholder model of brand equity. Journal of Brand Management, Vol. 13 No 1, pp. 10-32.

Jöreskog, K.G. (1993): Testing structural equations models. In: Bollen, K.A. and Long, J.S. (eds.) Testing Structural Equation Models. Sage, Newbury Park CA.

Juga J., Juntunen, J. and Grant, D.B. (2010) Service quality and its relation to satisfaction and loyalty in logistics and outsourcing relationships. Managing Service Quality Vol. 20 No 6, pp. 496-510.

Juga, J., Juntunen, J. and Juntunen M. (2012), Impact of service quality, image and relational aspects on satisfaction and loyalty in logistics outsourcing relationships. International Journal of Shipping and Transport Logistics, Vol. 4, No 1, pp. 17-28.

Juntunen, J., Juntunen, M. and Juga, J. (2015), Latent classes of service quality, logistics costs and loyalty. International Journal of Logistics: Research and Applications, Vol 18 No 5, pp. 442-458.

Keller, K.L. (1998), Strategic Brand Management. Prentice-Hall, Englewood Cliffs NJ.

Krishnan, B.C. and Hartline, M.D. (2001), Brand equity: is it more important in services? Journal of Services Marketing, Vol. 15, No 5, pp. 328-342.

Ladhari, R. (2009), A review of twenty years of SERVQUAL research. International Journal of Quality and Service Sciences, Vol. 1 No 2, pp. 172-198.

Lam, S.Y., Shankar, V., Erramilli, K. and Murthy, B. (2004), Customer value, satisfaction, loyalty, and switching costs: An illustration from a business-to-business service context. Journal of the Academy of Marketing Science, Vol. 32 No 3, pp. 293-311.

Larson, P.D. (2005), A note on mail surveys and response rates in logistics research. Journal of Business Logistics, Vol. 26 No. 2, pp. 211-22.

Leek, S., and Christodoulides, G. (2011), A literature review and future agenda for B2B branding: Challenges of branding in a B2B context. Industrial Marketing Management, Vol. 40 No 6, pp. 830-837.

Juntuen, M., Juntunen, J. and Juga, J. (2011), Corporate brand equity and loyalty in B2B markets: A study among logistics service purchasers. Journal of Brand Management, Vol. 18 No 4-5, pp. 300-311.

Leuthesser, L., Kohli, C.S. and Harich, K.R. (1995), Brand equity: the halo effect measure. European Journal of Marketing, Vol. 29 No 4, pp. 57-66. 
Mäläskä, M. (2015), Co-creation of corporate brand through stakeholder relationships in B2B SMEs. Acta Universitatis Ouluensis G74, University of Oulu, Oulu.

Martensen, A. and Grønholdt (2010), Measuring and managing brand equity: A study with focus on product and service quality in banking. International Journal of Quality and Service Sciences, Vol. 2 No 3, pp. 300-316.

McDougall, G.H.G. and Levesque, T. (2000), Customer satisfaction with services: Putting perceived value into the equation. Journal of Services Marketing, Vol. 14 No 5, pp. 392410.

Mentzer , J.T., Flint, D.J. and Kent, J.L. (1999) Developing a Logistics Service Quality Scale. Journal of Business Logistics, Vol. 20 No 1, pp. 9-32.

Mentzer, J.T., Flint, D.J., Hult, T. and Tomas, M. (2001), Logistics service quality as a segment-customized process. Journal of Marketing, Vol 65 No 4, pp. 82-103.

Olsen, S.O. (2002), Relationship between quality, satisfaction and repurchase loyalty. Journal of the Academy of Marketing Science, Vol. 30 No 3, pp. 240-249.

Rafele, C. (2004) Logistic Service Measurement: A Reference Framework. Journal of Manufacturing Technology Management, Vol. 15 No 3, pp. 280-290.

Rafiq, M. and Jaafar, H.S. (2007), Measuring customers' perceptions of logistics service quality of 3PL service providers. Journal of Business Logistics, Vol. 28 No 2, pp. 157175.

Rauyruen, P. and Miller, K.E. (2007), Relationship quality as a predictor of B2B customer loyalty. Journal of Business Research, Vol. 60, No 1, pp. 21-31.

Rauyruen, P., Miller, K.E. and Groth, M. (2009), B2B services: linking service loyalty and brand equity. Journal of Services Marketing, Vol. 23 No 3, pp. 175-186.

Reicheld, F.F., Markey, R.G. Jr, Hopton, C. (2000), The loyalty effect: The relationship between loyalty and profits. European Business Journal, Vol. 12 No 3, pp. 134-139.

Rigopoulou, I.D., Chaniotakis, I.E., Lymperopoulos, C. and Siomkos, G.I. (2008), Aftersales service quality as an antecedent of customer satisfaction. Managing Service Quality: An International Journal, Vol. 18, No 5, pp. 512-527.

Saura, I.G., Servera Francés, D., Benguer Contrí, G. and Fuentes Blasco, M. (2008), Logistics service quality: a new way to loyalty. Industrial Management \& Data Systems, Vol. 108 No 5, pp. 650-668.

Seth, N., Desmukh, S.G. and Vrat, P. (2005), Service quality models: A review. International Journal of Quality \& Reliability Management, Vol. 22 No 9, pp. 913-949.

Stank, T.P., Goldsby, T.J., Vickery, S.K. and Savitskie, K. (2003), Logistics service performance: Estimating its influence on market share. Journal of Business Logistics, Vol. 24 No 1, pp. 27-55.

Taylor, S.A., Celuch, K. and Goodwin, S. (2004), The importance of brand to customer loyalty. Journal of Product \& Brand Management, Vol. 13 No 4, pp. 217-227.

Van Riel, A.C.R., Pahud de Mortanges, C. and Streukens, S. (2005), Marketing antecedents of industrial brand equity: An empirical investigation in specialty chemicals. Industrial Marketing Management, Vol. 34 No 8, pp. 841-847.

Vogel, V., Evanschitzky, H., and Ramaseshan, B. (2008), Customer equity drivers and future sales. Journal of Marketing, Vol 72 No 6, pp. 98-108. 
Wallenburg, C.M., Cahill, D.L., Goldsby, T.J. and Knemeyer, A.M. (2010), Logistics outsourcing performance and loyalty behaviour: Comparisons between Germany and the United States. International Journal of Physical Distribution \& Logistics Management, Vol. 40 No 7, pp. 579-602

Wood, L. (2000), Brands and brand equity: Definition and management. Management Decision, Vol. 38 No 9, pp. 662-669. 
Table 1. Key descriptives of the respondent companies

\begin{tabular}{|lc|lc|}
\hline \multicolumn{2}{l|}{ Customer company's size $(\mathrm{N}=172)$} & \multicolumn{3}{l|}{ Duration of customer relationship $(\mathrm{N}=170)$} \\
\hline max 5 persons & 69 & max 2 years & 48 \\
6-10 persons & 33 & $3-5$ years & 45 \\
$11-20$ persons & 25 & $6-9$ years & 25 \\
21-40 persons & 17 & $10-15$ years & 28 \\
over 40 persons & 29 & over 15 years & 26 \\
\hline
\end{tabular}

Table 2. Concepts and operational measures

\begin{tabular}{|c|c|c|}
\hline $\begin{array}{l}\text { Latent } \\
\text { variable }\end{array}$ & Operational measures in the questionnaire & Label \\
\hline $\begin{array}{l}\text { Operational } \\
\text { service }\end{array}$ & $\begin{array}{l}\text { Based on recent experiences with [brewery], evaluate the } \\
\text { service in terms of (scale: } 1=\text { poor } \ldots 7=\text { excellent) })^{a} \text { : } \\
\text { - ability to keep schedules } \\
\text { - ability to offer products promptly } \\
\text { - ability to provide sufficient capacity }\end{array}$ & $\begin{array}{l}\text { OSERV } \\
\text { OS1 } \\
\text { OS2 } \\
\text { OS3 }\end{array}$ \\
\hline $\begin{array}{l}\text { Personal } \\
\text { service }\end{array}$ & $\begin{array}{l}\text { Based on recent experiences with [brewery], evaluate the } \\
\text { service in terms of (scale: } 1=\text { poor } \ldots 7=\text { excellent) })^{\text {a) }} \\
\text { - service-mindedness of personnel } \\
\text { - accessibility of personnel } \\
\text { - expertise of personnel }\end{array}$ & $\begin{array}{l}\text { PSERV } \\
\text { PS1 } \\
\text { PS2 } \\
\text { PS3 }\end{array}$ \\
\hline $\begin{array}{l}\text { Technical } \\
\text { service }\end{array}$ & $\begin{array}{l}\text { Based on recent experiences with [brewery], evaluate the } \\
\text { service in terms of (scale: } 1=\text { poor } \ldots 7=\text { excellent) })^{a} \text { : } \\
\text { - technical level of information systems } \\
\text { - technical quality of information systems } \\
\text { - problem-free electronic communication }\end{array}$ & $\begin{array}{l}\text { TSERV } \\
\text { TS1 } \\
\text { TS2 } \\
\text { TS3 }\end{array}$ \\
\hline $\begin{array}{l}\text { Value adding } \\
\text { service }\end{array}$ & $\begin{array}{l}\text { Based on recent experiences with [brewery], evaluate the } \\
\text { service in terms of (scale: } 1=\text { poor ... } 7 \text { = excellent): } \\
\text { - devices and device maintenance } \\
\text { - logistics } \\
\text { - transportation }\end{array}$ & $\begin{array}{l}\text { VALUEADD } \\
\text { VA1 } \\
\text { VA2 } \\
\text { VA3 }\end{array}$ \\
\hline Loyalty & $\begin{array}{l}\text { Indicate your intentions regarding relationship continuity } \\
\text { (scale: } 1=\text { fully disagree } \ldots 7=\text { fully agree })^{\text {b) }} \\
\text { - We are likely to recommend [brewery] to our business } \\
\text { partners. } \\
\text { - With high probability we will continue the relationship with } \\
\text { [brewery] as long as possible. }\end{array}$ & $\begin{array}{l}\text { LOYAL } \\
\text { L1 } \\
\text { L2 }\end{array}$ \\
\hline Brand equity & $\begin{array}{l}\text { Give your impression regarding [brewery] (scale: } 1 \text { = fully } \\
\text { disagree } \ldots 7=\text { fully agree) }{ }^{c} \text { : } \\
\text { - We are willing to pay more in order to do business with } \\
\text { [brewery] } \\
\text { - This company's brand is different from other breweries } \\
\text { - The name of [brewery] gives them an advantage over other } \\
\text { breweries }\end{array}$ & $\begin{array}{l}\text { BE } \\
\text { BE1 } \\
\text { BE2 } \\
\text { BE3 }\end{array}$ \\
\hline
\end{tabular}


Table 3. Test statistics of the empirical model

\begin{tabular}{|lrr|lrrrrl|}
\hline Final model & & & \multicolumn{2}{l}{ Latent variables } \\
Test & Value & P-value & & CR & AVE & VAVE & Alpha \\
\hline Chi-square (df) & $218.33(111)$ & 0.000 & OSERV & 0.850 & 0.663 & 0.814 & 0.827 \\
RMSEA & 0.075 & & PSERV & 0.929 & 0.709 & 0.842 & 0.936 \\
CFI & 0.979 & & TSERV & 0.930 & 0.710 & 0.843 & 0.935 \\
TLI (NNFI) & 0.975 & & SERV & - & - & - & - \\
SRMR & 0.068 & & VALUEADD & 0.866 & 0.674 & 0.821 & 0.816 \\
& & & LOYAL & 0.663 & 0.500 & 0.707 & 0.735 \\
& & & BRANDEQ & 0.749 & 0.602 & 0.776 & 0.746 \\
\hline
\end{tabular}

Table 4. Study results regarding proposed hypotheses

\begin{tabular}{|lll|}
\hline Hypothesis & Description & Decision \\
\hline H1a & Operational service quality is a dimension of overall quality & Accepted \\
H1c & Personal service quality is a dimension of overall quality & Accepted \\
H2a & Technical service quality is a dimension of overall quality & Accepted \\
H2b & Value-adding services is an antecedent to operational quality & Accepted \\
H2c & Value-adding services is an antecedent to personal quality & Accepted \\
H3 & Value-adding services is an antecedent to technical quality & Rejected \\
H4 & Value-adding services is an antecedent to total quality & Accepted \\
H5 & Total quality is an antecedent to loyalty intention & Accepted \\
H6 & Total quality is an antecedent to brand equity & Accepted \\
\hline
\end{tabular}




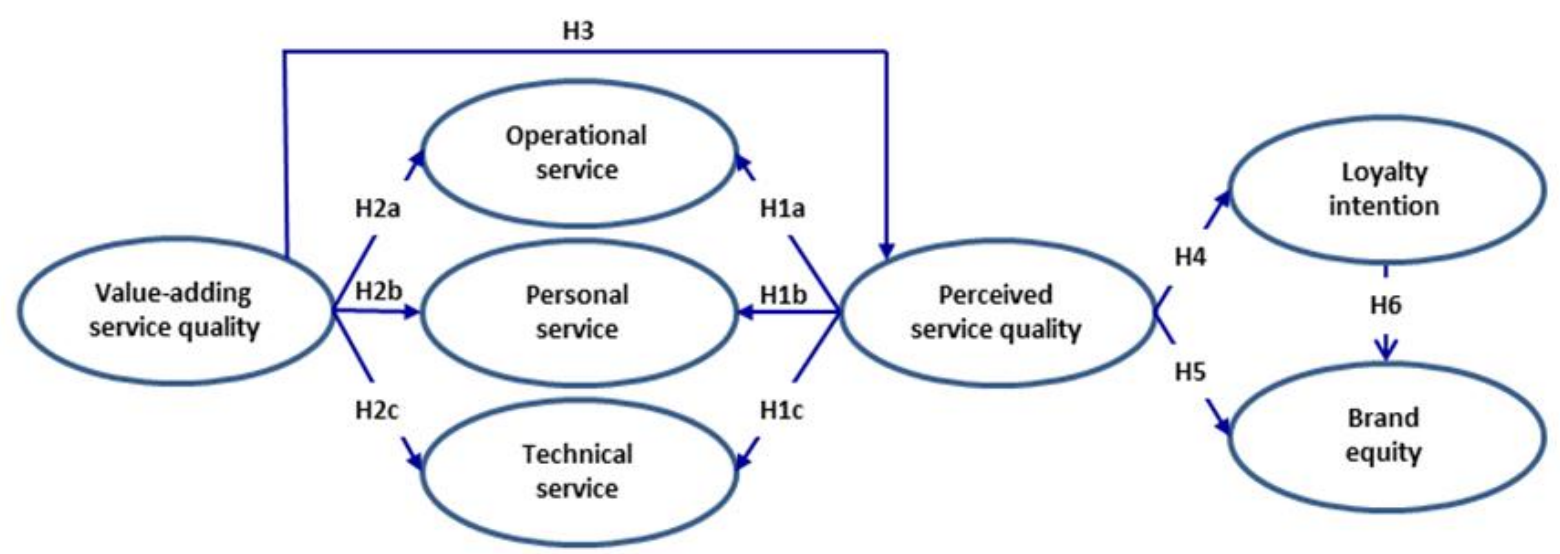

Figure 1. Theoretical model with hypothesized relationships between concepts

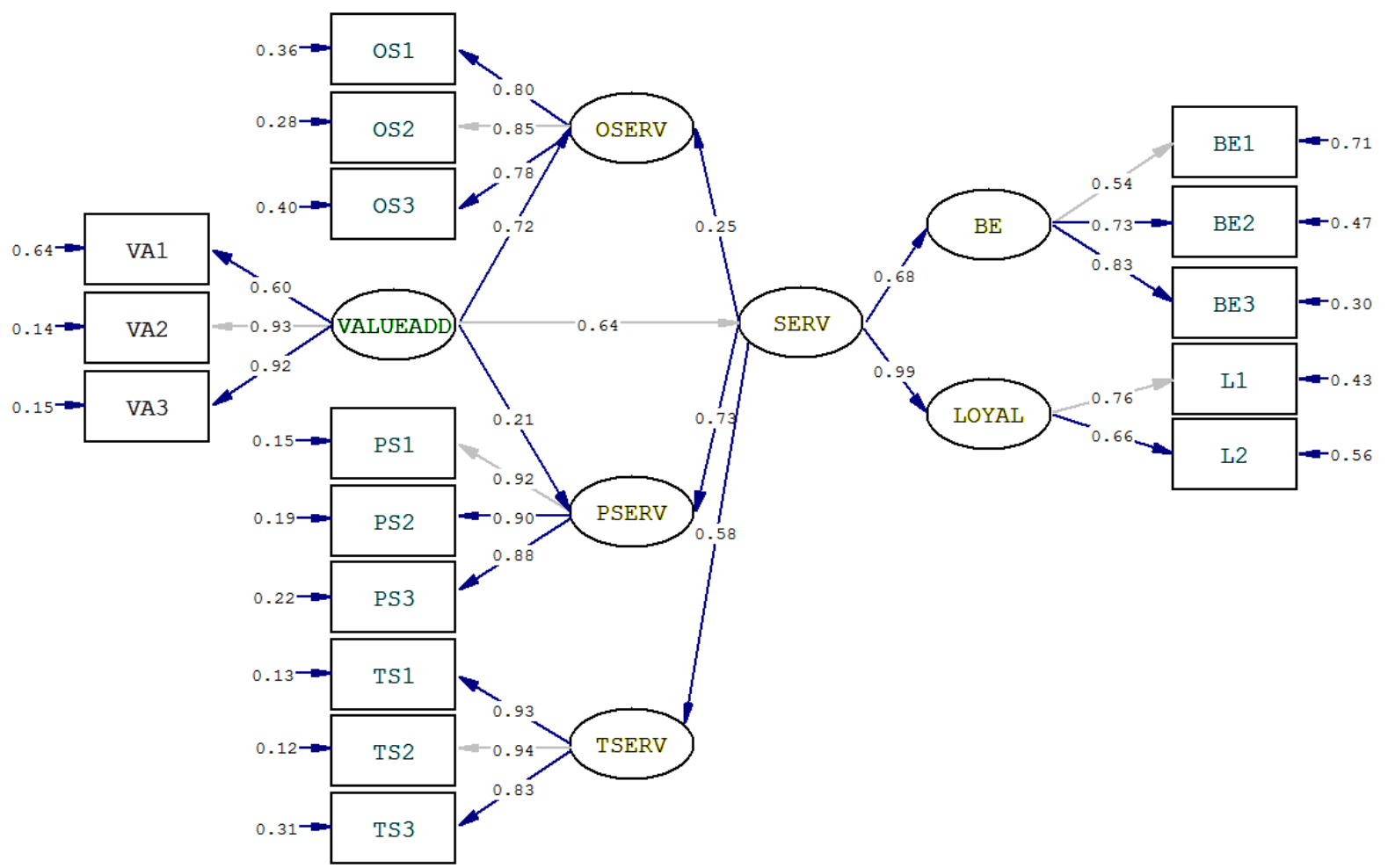

Figure 2. The empirical model 